\title{
Consumers' Willingness to Pay for Organic Fresh Milk in Saudi Arabia
}

\author{
Amal Almarri ${ }^{1}$ and Mohammed Al-Mahish ${ }^{2 *}$
}

Received: 01 $1^{\text {st }}$ January 2020 / Accepted: 04 ${ }^{\text {th }}$ August 2021

\section{ABSTRACT}

Purpose: Consumption of organic food among consumers in Saudi Arabia has increased in recent times due to increased awareness of health benefits of organic food. The purpose of this paper is to estimate the average amount a consumer is willing to pay in Saudi Arabia for fresh organic milk.

Research Method: This paper used the Double Bounded Dichotomous Choice (DBDC) model to identify key determinants of consumers' willingness to pay (WTP) for fresh organic milk.

Findings: The results showed that organic product label, consumers' awareness about nutritional benefits of organic milk, agility, and income were key determinants of consumers' WTP for fresh organic milk. The paper estimated average consumers' willingness to pay for one litre of fresh organic milk to be SAR 14 while the nonparametric estimates of WTP ranged in values from as low as SAR 10 to as high as 12 SAR.

Originality/value: The results are important to the domestic dairy companies and existing European organic long-life milk exporters to Saudi Arabia to initiate business ventures on organic fresh milk business.

Keywords: Double Bounded Dichotomous Choice, Organic, Willingness to Pay, Saudi Arabia.

\section{INTRODUCTION}

Health awareness among consumers in developed countries and emerging developing countries has led to the prosperity of the organic food industry (Muhammad, Fathelrahman and Ullah, 2015). The size of organic food industry has evolved at an exponential rate. Fruits and vegetables emerged as the largest organic food product segment in 2015, and it is expected to generate an estimated revenue of over USD 110 billion by 2025 (Grand View Research, 2017).This promising industry has directed economic institutes and investors to start investing in organic products. Globenewswire, 2019 indicated that almost $80 \%$ of organic food in Saudi Arabia is imported from Western countries, however, the government has launched many initiatives to support organic farming. Thus, consumers in Saudi Arabia are expected to consume more organic foods.

Saudi Arabia is self-sufficient in conventional milk production, and self-sufficiency ratio in 2019 reached 109\% (Ministry of Environment, 2019). Traditional milk production in the Kingdom of Saudi Arabia consists of three types of production; goat's milk, cow's milk and camel milk. In 2019, dairy companies produced 136 million tons of camel milk, 2201 millions of cow's milk. In 2014, the amount of goat milk production reached 65 million tons. The average production of camel milk during the period from 2004 to 2019 was about 107.9 million tons, 1678.4 million tons for cow's milk, and 75.8 tons for goat milk. It is noted that the main source of traditional milk production in the Kingdom of Saudi Arabia is cow's milk followed by camel milk and then goat milk (FAO, 2021). However, domestic milk producers do not produce organic milk, and Saudi Arabia imports long-life (also

\footnotetext{
Department of Agribusiness and Consumer Science, College of Agriculture and Food Science, King Faisal University.

malmahish@kfu.edu.sa; mohammed_9m@yahoo.com

https://orcid.org/0000-0002-8143-1114
} 
known as ultra-heated temperature (UHT)) organic milk mostly from European producers. Hence, the study tries to answer the following research question:

Is it possible to estimate an average price that a consumer in Saudi Arabia is willing to pay for a commodity that is not available in domestic market (fresh organic milk)? Revealing the average price is a vital information for domestic companies and foreign investors since it is the main determinant for them to make a decision to invest in organic milk in Saudi Arabia. As a result, the purpose of this paper is to use the Dichotomous Choice Contingent Valuation (DCCV) method to estimate average consumers' willingness to pay (WTP) for organic fresh milk in Eastern Region of Saudi Arabia. Also, the paper is aimed at revealing the effect of organic milk characteristics such as product's labels and type of packaging on consumers' WTP. Moreover, the impact of consumers' demographic and socio-economic status, consumers' awareness, and preference on their WTP for fresh, organic milk, were examined.

Consumption of organic food has risen due to an increase in consumers' educational and income level, however, the price of organic food may be a concern for potential consumers (Voon et al., 2011). As a result, Padilla Bravo et al., (2013) suggested to reduce the price of organic food to motivate consumers to purchase them. In addition, families with two and more children are less likely to purchase organic food in Australia compared to smaller household sizes (Ward et al., 2012). Chen and Lobo (2012) mentioned that Chinese consumers are generally unaware of organic food because it is a new concept for them. Also, the authors stated that urban Chinese consumers' consumption of organic food is affected by consumers' lifestyles. Cultural influence was also found to be a determinant of organic food consumption in Italy (Agovino et al., 2017).

A study conducted by Krystallis and Chryssohoidis (2005) identified that 12\% of consumers in Greece were willing to pay a 105-120 percent higher price for organic milk in relation to conventional milk prices. According to Muhammad et al., (2015), socio- economics factors including age, income, nationality, education level, and household size had a significant impact on consumers' WTP for organic products in the United Arab Emirates.

Akaichi, Nayga and Gil (2012) stated that the main reasons for consumers' unwillingness to buy organic milk were unavailability, lack of nutritional facts label and an expensive pricing.

Huang and Lee (2014) identified that age, labels of the organic milk products and organic-certified attributes had a significant impact on WTP for organic milk. Also, the estimated median WTP for organic fresh milk was $\$ 21.95$ annually. As mentioned by Amirnejad and Tonakbar (2015), the estimated average consumers' WTP for organic milk was significantly affected by the consumers' age, income, and education level. In addition, the estimated average consumers' WTP for organic milk was 28,600 Iranian Riyal per liter.

To the authors' knowledge, this is the first study to estimate the average consumers' WTP for organic milk in Saudi Arabia. Also, the study will provide empirical estimates of the average consumers' WTP using both parametric and non-parametric methods. These results are useful for researchers who are interested in comparing the performance of parametric and non-parametric methods.

\section{MATERIALS AND METHODS}

The most popular contingent valuation surveys for eliciting consumers' WTP for a new service or a product are SBDC (Bishop and Heberlein, 1979) and DBDC. In the SBDC survey, consumers are given a bid and then are asked whether they will be willing to pay a specific value for a product or a service. Although, this type of survey is easier for both the researcher to collect and design the survey as well as to consumers to respond, indicated that the SBDC is inefficient compared to DBDC (Hanemann, Loomis and Kanninen, 1991). Therefore, DBDC method was used to elicit Saudi consumers' WTP for fresh, organic milk. In the DBDC, the consumers were given a bid and then were asked if they would be willing to pay that bid for organic, fresh milk. If a consumer accepted 
the first bid, then he/she was given a follow-up higher bid. Conversely, if a consumer rejected the first bid, then he/she was given a lower bid. Thus, the responses for DBDC survey were as below: [Yes, Yes], [Yes, No], [No, Yes], and [No, No].

The bid in this study was designed after noticing that the price for one liter of fresh conventional milk was the same as the price for one liter of conventional long-life milk. Thus, any prospective dairy firm which may enter the organic fresh milk market has to consider competitors' prices, i.e. the prevailing prices of imported long-life milk. Thus, the starting bid was designed based on the observed prices for one liter of imported long-life organic milk in grocery stores. Then the second bid was a function in the price of the first bid and the difference between the first bid price and the price for one litter of conventional fresh milk.

In case of the SBDC, the probability that a consumer accepts, $\mathrm{P}^{\mathrm{Y}}$, the offered bid (s) in logit model is (Aizaki, Nakatani and Sato, 2014):

$P^{Y}(s)=\frac{1}{\exp (-a+\beta s)}$

The log-likelihood function is expressed as below:

$\ln L=\sum_{n=1}^{N}\left[d_{n} \ln \left\{\frac{1}{\exp (-a+\beta s)}\right\}+\left(1-d_{n}\right) \ln \left\{1-\frac{1}{\exp (-a+\beta s)}\right\}\right]$

Where $d_{n}$ is a dummy variable that equals one if a consumer accepts the bid, and zero if a consumer rejects the bid.

The parameters of the logit model are then used to calculate the mean consumers' WTP for organic fresh milk as below:

mean $W T P=\int_{0}^{\infty}[1-F(s) d s]$

Where $F(s)$ is the cumulative distribution function of the consumers' WTP.

Economic theory states that a consumer's WTP should not exceed his/her income level. However, equation (3) implies that some consumers may be willing to pay an amount that exceeds his/her income level (Aizaki, Nakatani and Sato, 2014). Thus, it is recommended to report the truncated mean WTP, which is calculated as below (Boyle, Welsh and Bishop, 1988):

Truncated mean $W T P=\int_{0}^{s \max }\left[\frac{1-F(s)}{F\left(s_{\max }\right)}\right] d s$

The median consumers' WTP is usually reported because it is more robust to include outliers and errors compared to the mean WTP (Hanemann, 1984).

median $W T P=F^{-1}(0.5)$

For the case of DBDC, the probability that a consumer accepts the first and second bid, $P^{Y Y}$, is:

$$
P^{Y Y}(s)=\frac{1}{\exp \left(-a+\beta s_{n}^{h}\right)}
$$

And the probability that a consumer rejects the first and second bid, $P^{N N}$, is:

$$
P^{N N}(s)=1-\frac{1}{\exp \left(-a+\beta s_{n}^{L}\right)}
$$

The probability that a consumer accepts the first bid and rejects the second bid, $\mathrm{P}^{Y N}$, is:

$$
P^{Y N}(s)=\left\{1-\frac{1}{\exp \left(-a+\beta s_{n}^{h}\right)}\right\}-\left\{1-\frac{1}{\exp \left(-a+\beta s_{n}\right)}\right\}
$$

The probability that a consumer rejects the first bid and accepts the second bid, $\mathrm{P}^{N Y}$, is:

$$
P^{N Y}(s)=\left\{1-\frac{1}{\exp \left(-a+\beta s_{n}\right)}\right\}-\left\{1-\frac{1}{\exp \left(-a+\beta s_{n}^{L}\right)}\right\}
$$

Where $\mathrm{s}_{\mathrm{n}}{ }^{\mathrm{h}}$ and $\mathrm{s}_{\mathrm{n}}{ }^{\mathrm{L}}$ denotes the second higher and lower bid respectively. Lastly, the log-likelihood function for the DBDC model is: 


$$
\begin{gathered}
\ln L=\sum_{n=1}^{N}\left[d_{n}^{Y Y} \ln \left\{\exp \left(a-\beta s_{n}^{h}\right)\right\}+d_{n}^{N N} \ln \left\{1-\exp \left(a-\beta s_{n}^{L}\right)\right\}+d_{n}^{Y N} \ln \left\{\exp \left(a-\beta s_{n}\right)-\right.\right. \\
\left.\left.\exp \left(a-\beta s_{n}^{h}\right)\right\}+d_{n}^{N Y} \ln \left\{\exp \left(a-\beta s_{N}^{L}\right)-\exp \left(a-\beta s_{n}\right)\right\}\right]
\end{gathered}
$$

Where $d_{n}{ }^{Y Y}$ is a binary variable that will equal one, if a consumer $n$ accepts the first and second bids and zero otherwise; $d_{n}{ }^{Y N}$ will equal one, if a consumer $n$ accepts the first bid but rejects the second bid and zero otherwise; $d_{n}^{N Y}$ will equal one, if a consumer $\mathrm{n}$ rejects the first bid but accepts the second bid; and $d_{n}^{N N}$ will equal one, if a consumer $\mathrm{n}$ rejects the first and second bid and zero otherwise.

The sample size was determined in accordance with the guidelines stated by (Vaughan and Darling, 2000) by ensuring at least 120 respondents per bid group. Thus, the total number of respondents consisted of 500 consumers.

\section{RESULTS AND DISCUSSION}

Table 1,2 shows the summary of the survey results. $92 \%$ of respondents were Saudis while the proportion of non-Saudis was $8 \%$. Also, $60 \%$ of respondents were women. Almost half of the respondents were married, and the other half were unmarried, $86 \%$ of them had a knowledge about organic milk and $14 \%$ of them did not. Approximately, 52\% of respondents preferred to purchase one liter of milk (medium size), and $54 \%$ preferred the plastic packaging. The majority of respondents (over $80 \%$ ) were aware about the nutritional benefits of organic milk and preferred fresh milk over long-life milk. Moreover, most of respondents agreed that both quality and "organic product" labels on milk packaging influenced their intention to purchase organic milk. Furthermore, half of respondents who had bought imported organic milk attributed their purchase decision to health and treatment purposes. Also, most of the respondents (over 80\%) accepted the first bid. However, the results of consumers' response to second bid differed based on bid group and the bid that was given to them.

The results of estimated parameters for both the DBDC and SBDC are shown in Table 3. The results show that the "organic product" label is statistically significant at the five percent in both models. This indicates that consumers who reported organic products' labels affecting their purchase decision are more likely to pay for organic, fresh milk than those consumers who are indifferent with "organic product" labels. The results in both models show that as consumers' income increases, they will be more willing to pay for organic, fresh milk. Also, squared income term is significant in both models indicating a curvilinear effect. Furthermore, consumers who attributed their purchase of imported organic long-life milk just to try it are less likely to be willing to pay for organic, fresh milk compared to consumers who bought it to maintain their agility. Moreover, both the SBDC and DBDC model confirm that consumers who are aware of organic milk nutritional value are more likely to pay for organic, fresh milk than those who are unfamiliar with the nutritional benefits of organic, fresh milk. The DBDC model shows that consumers who prefer glass packaging are less likely to pay for organic, fresh milk than those who prefer carton packaging. Also, consumers who prefer long-life milk are less likely to be willing to pay for organic, fresh milk. Lastly, single consumers are more likely to be willing to pay for organic, fresh milk than married consumers. 
Table 01: Summary of respondents' demographic and socioeconomic characteristics

\begin{tabular}{|c|c|c|c|c|c|}
\hline Variable & $\mathbf{N}$ & $\%$ & Variable & $\mathbf{N}$ & $\%$ \\
\hline $\begin{array}{l}\text { Age } \\
<20 \text { years old } \\
20-30 \text { years old } \\
31-40 \text { years old } \\
41-50 \text { years old } \\
51-60 \text { years old } \\
\text { Above } 60 \text { years old }\end{array}$ & $\begin{array}{c}52 \\
273 \\
106 \\
50 \\
16 \\
3\end{array}$ & $\begin{array}{l}11 \% \\
54 \% \\
21 \% \\
10 \% \\
3 \% \\
1 \%\end{array}$ & $\begin{array}{l}\text { If you have purchased an } \\
\text { organic milk before, what was } \\
\text { the reason for your purchase? } \\
\text { Health maintenance and } \\
\text { treatment. It tastes better than } \\
\text { traditional products Just to } \\
\text { try Agility To conserve the } \\
\text { environment }\end{array}$ & $\begin{array}{c}262 \\
99 \\
70 \\
36 \\
33\end{array}$ & $\begin{array}{c}52.40 \% \\
19.80 \% \\
\\
14 \% \\
7.20 \% \\
6.60 \%\end{array}$ \\
\hline $\begin{array}{l}\text { Marital status } \\
\text { Married } \\
\text { Single }\end{array}$ & $\begin{array}{l}242 \\
258\end{array}$ & $\begin{array}{l}48.40 \% \\
51.60 \%\end{array}$ & $\begin{array}{c}\text { Does the quality of your milk } \\
\text { affect your purchase? } \\
\text { Yes } \\
\text { No }\end{array}$ & $\begin{array}{c}467 \\
33\end{array}$ & $\begin{array}{c}93.25 \% \\
6.75\end{array}$ \\
\hline $\begin{array}{l}\text { Sex } \\
\text { Male } \\
\text { Female }\end{array}$ & $\begin{array}{l}201 \\
299\end{array}$ & $\begin{array}{l}39.74 \% \\
60.26 \%\end{array}$ & $\begin{array}{c}\text { Are you aware of the } \\
\text { nutritional value of fresh, } \\
\text { organic milk? } \\
\text { Yes } \\
\text { No } \\
\end{array}$ & $\begin{array}{c}410 \\
90\end{array}$ & $\begin{array}{l}82 \% \\
18 \%\end{array}$ \\
\hline $\begin{array}{l}\text { Education } \\
\text { Primary school } \\
\text { Middle school } \\
\text { Secondary school } \\
\text { University } \\
\end{array}$ & $\begin{array}{c}6 \\
17 \\
115 \\
362 \\
\end{array}$ & $\begin{array}{c}1.20 \% \\
3.40 \% \\
23 \% \\
72.40 \% \\
\end{array}$ & $\begin{array}{c}\text { Favorite packaging } \\
\text { Plastic } \\
\text { Glass } \\
\text { Cartons }\end{array}$ & $\begin{array}{l}271 \\
107 \\
122\end{array}$ & $\begin{array}{l}54.20 \% \\
21.40 \% \\
24.40 \%\end{array}$ \\
\hline $\begin{array}{l}\text { Income } \\
<1000 \text { R.S } \\
1000-6000 \text { R.S } \\
6001-12000 \\
12001-20000 \\
>20,000 \text { R.S }\end{array}$ & $\begin{array}{c}60 \\
297 \\
79 \\
53 \\
11\end{array}$ & $\begin{array}{c}12.56 \% \\
58.14 \% \\
16.09 \% \\
10.71 \% \\
2.15 \%\end{array}$ & $\begin{array}{l}\text { Does "Organic Product" } \\
\text { label affect your decision to } \\
\text { purchase organic milk? } \\
\text { Yes } \\
\text { No }\end{array}$ & $\begin{array}{c}411 \\
89\end{array}$ & $\begin{array}{l}82.20 \% \\
17.80 \%\end{array}$ \\
\hline $\begin{array}{l}\text { Nationality } \\
\text { Saudi } \\
\text { Non-Saudi }\end{array}$ & $\begin{array}{c}458 \\
42\end{array}$ & $\begin{array}{c}91.70 \% \\
8.30 \%\end{array}$ & $\begin{array}{l}\text { Which do you prefer? } \\
\text { Fresh milk } \\
\text { Long-Life Milk }\end{array}$ & $\begin{array}{c}408 \\
92\end{array}$ & $\begin{array}{l}81.70 \% \\
18.30 \%\end{array}$ \\
\hline $\begin{array}{l}\text { Do you have prior knowledge } \\
\text { about the meaning of "organic } \\
\text { product"? } \\
\text { Yes } \\
\text { No }\end{array}$ & $\begin{array}{c}428 \\
72\end{array}$ & $\begin{array}{l}85.60 \% \\
14.40 \%\end{array}$ & $\begin{array}{c}\text { How much do you spend on } \\
\text { milk in a week? } \\
<\text { SAR } 20 \\
\text { SAR 20-SAR 30 } \\
\text { SAR 31-SAR 40 } \\
\text { SAR 41-SAR 50 } \\
\text { >SAR 50 }\end{array}$ & $\begin{array}{l}139 \\
185 \\
45 \\
57 \\
74\end{array}$ & $\begin{array}{c}28 \% \\
37 \% \\
9 \% \\
11 \% \\
15 \%\end{array}$ \\
\hline $\begin{array}{l}\text { Favorite size } \\
\text { Very large }(2.85 \text { liters }) \\
\text { Large }(2 \text { liters }) \\
\text { Medium }(1 \text { liter }) \\
\text { Small Size }(500 \mathrm{ml})\end{array}$ & $\begin{array}{c}38 \\
125 \\
259 \\
78\end{array}$ & $\begin{array}{c}7.60 \% \\
25.00 \% \\
51.80 \% \\
15 \%\end{array}$ & $\begin{array}{c}\text { On average, how many milk } \\
\text { packs do you purchase per } \\
\text { week? } \\
<5 \\
5-8 \\
>8 \\
\end{array}$ & $\begin{array}{c}342 \\
137 \\
21 \\
\end{array}$ & $\begin{array}{l}69 \% \\
26 \% \\
5 \% \\
\end{array}$ \\
\hline
\end{tabular}


Table 02: $\quad$ Summary of WTP

\begin{tabular}{|c|c|c|c|c|c|}
\hline Variable & $\mathbf{N}$ & $\%$ & Variable & $\mathbf{N}$ & $\%$ \\
\hline $\begin{array}{l}\text { Does the quality of your milk } \\
\text { affect your purchase? } \\
\text { Yes } \\
\text { No }\end{array}$ & $\begin{array}{l}467 \\
33\end{array}$ & $\begin{array}{l}93.25 \% \\
6.75 \%\end{array}$ & $\begin{array}{l}\text { Are you willing to pay } 11.4 \\
\text { SAR to purchase fresh, organic } \\
\text { milk (1 liter)? } \\
\text { Yes } \\
\text { No }\end{array}$ & $\begin{array}{l}95 \\
11\end{array}$ & $\begin{array}{l}89.62 \% \\
10.38 \%\end{array}$ \\
\hline $\begin{array}{l}\text { Are you aware of the nutritional } \\
\text { value of fresh, organic milk? } \\
\text { Yes } \\
\text { No }\end{array}$ & $\begin{array}{l}410 \\
90\end{array}$ & $\begin{array}{l}82 \% \\
18 \%\end{array}$ & $\begin{array}{l}\text { Are you willing to pay } 8.63 \\
\text { SAR to purchase fresh, organic } \\
\text { milk (1 liter)? } \\
\text { Yes } \\
\text { No }\end{array}$ & $\begin{array}{l}5 \\
13\end{array}$ & $\begin{array}{l}27.78 \% \\
72.22 \%\end{array}$ \\
\hline $\begin{array}{l}\text { Are you willing to pay } 9.50 \mathrm{SAR} \\
\text { to purchase fresh, organic milk } \\
\text { (1 liter)? } \\
\text { Yes } \\
\text { No }\end{array}$ & $\begin{array}{l}109 \\
19\end{array}$ & $\begin{array}{l}84.35 \% \\
15.65 \%\end{array}$ & $\begin{array}{l}\text { Are you willing to pay 11SAR } \\
\text { to purchase fresh, organic milk } \\
\text { (1 liter)? } \\
\text { Yes } \\
\text { No }\end{array}$ & $\begin{array}{l}98 \\
24\end{array}$ & $\begin{array}{l}80.33 \% \\
19.67 \%\end{array}$ \\
\hline $\begin{array}{l}\text { Are you willing to pay } 10,75 \\
\text { SAR to purchase fresh, organic } \\
\text { milk (1 liter)? } \\
\text { Yes } \\
\text { No }\end{array}$ & $\begin{array}{l}84 \\
25\end{array}$ & $\begin{array}{l}77.36 \% \\
22.64 \%\end{array}$ & $\begin{array}{l}\text { Are you willing to pay } 12.63 \\
\text { SAR to purchase fresh, organic } \\
\text { milk (1 liter)? } \\
\text { Yes } \\
\text { No }\end{array}$ & $\begin{array}{l}62 \\
36\end{array}$ & $\begin{array}{l}60 \% \\
40 \%\end{array}$ \\
\hline $\begin{array}{l}\text { Are you willing to pay } 8,25 \mathrm{SAR} \\
\text { to purchase fresh, organic milk } \\
\text { (1 liter)? } \\
\text { Yes } \\
\text { No }\end{array}$ & $\begin{array}{l}6 \\
13\end{array}$ & $\begin{array}{l}31.58 \% \\
68.42 \%\end{array}$ & $\begin{array}{l}\text { Are you willing to pay } 9.38 \\
\text { SAR to purchase fresh, organic } \\
\text { milk (1 liter)? } \\
\text { Yes } \\
\text { No }\end{array}$ & $\begin{array}{l}12 \\
12\end{array}$ & $\begin{array}{l}50 \% \\
50 \%\end{array}$ \\
\hline $\begin{array}{l}\text { Are you willing to pay } 10 \text { SAR } \\
\text { to purchase fresh, organic milk } \\
\text { (1 liter)? } \\
\text { Yes } \\
\text { No }\end{array}$ & $\begin{array}{l}106 \\
18\end{array}$ & $\begin{array}{l}85.48 \% \\
14.52 \%\end{array}$ & $\begin{array}{l}\text { Are you willing to pay } 12 \text { SAR } \\
\text { to purchase fresh, organic milk } \\
\text { (1 liter)? } \\
\text { Yes } \\
\text { No }\end{array}$ & $\begin{array}{l}88 \\
38\end{array}$ & $\begin{array}{l}69.84 \% \\
30.16 \%\end{array}$ \\
\hline
\end{tabular}


Table 03: $\quad$ Parametric Estimation of SBDC and DBDC Models

\begin{tabular}{|c|c|c|}
\hline Variable & DBDC & SBDC \\
\hline Intercept & $\begin{array}{l}-4.56239 \\
(4.83274)\end{array}$ & $\begin{array}{l}-1.40256 \\
(6.02361)\end{array}$ \\
\hline Gender & $\begin{array}{c}0.33850 \\
(0.22655)\end{array}$ & $\begin{array}{c}0.18513 \\
(0.28319)\end{array}$ \\
\hline Organic Label & $\begin{array}{l}0.63999 * * \\
(0.24868)\end{array}$ & $\begin{array}{c}0.87820^{* * * *} \\
(0.29980)\end{array}$ \\
\hline Log (age) & $\begin{array}{l}-0.74976 \\
(0.53547)\end{array}$ & $\begin{array}{c}-1.49491 * * \\
(0.63882)\end{array}$ \\
\hline Log (income) & $\begin{array}{c}3.24754 * * * \\
(1.16020)\end{array}$ & $\begin{array}{c}2.87429 * * \\
(1.39209)\end{array}$ \\
\hline $\log (\text { income })^{2}$ & $\begin{array}{c}-0.20116 * * * \\
(0.07321)\end{array}$ & $\begin{array}{l}-0.17017 * \\
(0.08728)\end{array}$ \\
\hline Reason: Just to try it & $\begin{array}{c}-1.04629 * * \\
(0.42476)\end{array}$ & $\begin{array}{c}-1.15270^{* *} \\
(0.57201)\end{array}$ \\
\hline Reason: Health maintenance and treatment & $\begin{array}{c}0.24455 \\
(0.38680)\end{array}$ & $\begin{array}{l}-0.10265 \\
(0.54174)\end{array}$ \\
\hline Reason: It tastes better than conventional milk & $\begin{array}{l}-0.26855 \\
(0.41479)\end{array}$ & $\begin{array}{l}-0.42059 \\
(0.57230)\end{array}$ \\
\hline Reason: To conserve the environment & $\begin{array}{l}-0.51669 \\
(0.48307)\end{array}$ & $\begin{array}{l}-0.24178 \\
(0.68894)\end{array}$ \\
\hline Social status: Single & $\begin{array}{l}0.47627^{*} \\
(0.25200)\end{array}$ & $\begin{array}{c}0.32831 \\
(0.32466)\end{array}$ \\
\hline Favorite Packaging: glass & $\begin{array}{l}-0.75960 * \\
(0.30447)\end{array}$ & $\begin{array}{l}-0.44077 \\
(0.37066)\end{array}$ \\
\hline Favorite Packaging: Plastic & $\begin{array}{l}-0.26317 \\
(0.26212)\end{array}$ & $\begin{array}{l}-0.10666 \\
(0.32286)\end{array}$ \\
\hline Long-life milk preference & $\begin{array}{l}-0.45096 * \\
(0.25297)\end{array}$ & $\begin{array}{l}-0.15727 \\
(0.32996)\end{array}$ \\
\hline Nutritional value & $\begin{array}{l}0.44072 * \\
(0.25137)\end{array}$ & $\begin{array}{l}0.56573 * \\
(0.31273)\end{array}$ \\
\hline BID & $\begin{array}{c}-0.47745 * * * \\
(0.03770)\end{array}$ & $\begin{array}{c}-0.45234 * * * \\
(0.12672)\end{array}$ \\
\hline Log-Likelihood & -482.918 & -218.323 \\
\hline
\end{tabular}

Note: $\quad$ Standard errors are in parenthesis. $*, * *, * * *$ denote significance level at $10 \%, 5 \%$, and $1 \%$ respectively.

The parametric estimation of consumers' WTP for fresh, organic milk is shown in Table 4 along with their bootstrapped confidence intervals for both the SBDC and DBDC models. We used the bootstrap method to construct consumers' WTP because it is robust to model misspecification and noisy data (Hole, 2007). The average consumers' WTP for one liter of fresh, organic milk based on the DBDC model is SAR 13.75. With a 95\% confidence level, the average consumers' WTP for fresh, organic milk is in the range of SAR 13.23 - SAR 14.34. The truncated mean WTP is SAR 12.37 while the median WTP is SAR 13.74. 
Table 04: $\quad$ WTP Parametric Estimates

\begin{tabular}{lcccccc}
\hline & DBDC Model & \multicolumn{3}{c}{ SBDC Model } \\
\hline WTP & Estimate & $\begin{array}{c}\text { Lower } \\
\text { Confidence } \\
\text { Interval }\end{array}$ & $\begin{array}{c}\text { Upper } \\
\text { Confidence } \\
\text { Interval }\end{array}$ & Estimate & $\begin{array}{c}\text { Lower } \\
\text { Confidence } \\
\text { Interval }\end{array}$ & $\begin{array}{c}\text { Upper } \\
\text { Confidence } \\
\text { Interval }\end{array}$ \\
\hline Mean & 13.75104 & 13.234 & 14.341 & 14.23315 & 12.914 & 19.432 \\
Truncated & 12.37385 & 12.187 & 12.647 & 11.31606 & 10.940 & 11.585 \\
Mean & & 13.233 & 14.339 & 14.22961 & 12.914 & 19.309 \\
Median & 13.74809 & 13.96 & & & & \\
\hline
\end{tabular}

Table 05: Consumers' Mean WTP using Turnbull Nonparametric Methods

\begin{tabular}{lll}
\hline \multicolumn{1}{c}{ Method } & DBDC & SBDC \\
\hline Kaplan-Meier & SAR 11.740 & SAR 10.062 \\
Spearman-Karber & SAR 12.095 & SAR 10.825 \\
\hline
\end{tabular}

On the other hand, the SBDC model estimates the mean consumers' WTP for one liter of fresh, organic milk to be SAR 14.23 with a $95 \%$ confidence interval in the range of SAR 12.91 - SAR 19.43. Moreover, the SBDC estimated the truncated mean and median WTP to be SAR 11.31 and SAR 14.22, respectively.

In order to compare the parametric WTP estimation with the Turnbull Kaplan-Meier and Spearman-Karber nonparametric method (Aizaki et al., 2014), the estimated mean WTP based on the Spearmen-Karber method for both DBDC and SBDC, as shown in Table 5 , are very close to the truncated mean WTP that was estimated using the standard logistic distribution. However, the Kaplan-Meier mean WTP seems to underestimate average consumers' WTP compared to its parametric counterpart for the DBDC and SBDC models, respectively.

Our results are consistent with (Huang and Lee, 2014) and (Scozzafava et al., 2020) findings, which confirmed that the presence of the organic label has a significant impact on the consumer's willingness to pay for the organic product. Conversely, our study does not agree with (Nagy-Pércsi and Fogarassy, 2019) because they concluded that organic label is not important to consumers. Also, our findings are consistent with (Muhammad et al., 2015) since income was a significant determinant of consumers' willingness to pay. On the contrary, our study disagrees with (Zohra Ghali-Zinoubi, 2020) conclusion that pleasure had a greater impact on the desire to pay for organic food because our results showed that the elements of a healthy life style such as agility are also considered by consumers when deciding to purchase organic milk.

\section{CONCLUSIONS AND RECOMMENDATIONS}

Saudi Arabia is a self-sufficient country in conventional milk production; however, the country completely relies on imports to offer organic, long-life milk to domestic consumers. This paper has used the double bounded dichotomous choice (DBDC) contingent valuation method in order to estimate 
consumers' WTP for organic, fresh milk in the eastern region of Saudi Arabia. The survey results showed that the majority of consumers accepted the first bid for fresh, organic milk. The results also showed that consumers' awareness about nutritional benefits of organic milk, organic labels, agility, and income are significant determinants of consumers' WTP for fresh, organic milk. The paper estimated the average consumers' WTP for one liter of organic, fresh milk to be approximately SAR 14/liter. However, the nonparametric methods of the DBDC model estimate the average WTP to be approximately SAR 12/liter.

\section{REFERENCES}

Agovino, M. et al. (2017) 'Good Taste Tastes Good. Cultural Capital as a Determinant of Organic Food Purchase by Italian Consumers: Evidence and Policy Implications', Ecological Economics, 141, pp. 66-75. doi: 10.1016/j.ecolecon.2017.05.029.

Aizaki, H., Nakatani, T. and Sato, K. (2014) Stated Preference Methods Using R, Stated Preference Methods Using R. doi: 10.1201/b17292.

Akaichi, F., Nayga, R. M. and Gil, J. M. (2012) 'Assessing Consumers' Willingness to Pay for Different Units of Organic Milk: Evidence from Multiunit Auctions', Canadian Journal of Agricultural Economics, 60(4), pp. 469-494. doi: 10.1111/j.1744-7976.2012.01254.x.

Amirnejad, H. and Tonakbar, P. (2015) 'The willingness to pay for organic milk by consumers in Tehran', Journal of Agricultural Science and Technology, 17, pp. 1685-1694.

Bishop, R. C. and Heberlein, T. A. (1979) 'Measuring Values of Extramarket Goods: Are Indirect Measures Biased?', American Journal of Agricultural Economics, 61(5), pp. 926-930. doi: $10.2307 / 3180348$.

Boyle, K. J., Welsh, M. P. and Bishop, R. C. (1988) 'Validation of Empirical Measures of Welfare Change: Comment', Land Economics, 64(1), p. 94. doi: 10.2307/3146613.

Chen, J. and Lobo, A. (2012) 'Organic food products in China: determinants of consumers' purchase intentions', International Review of Retail, Distribution and Consumer Research, 22(3), pp. 293-314. doi: 10.1080/09593969.2012.682596.

FAO (2021). The Production Quantity of Milk in Saudi Arabia from (2004-2019), Available at: http://www.fao.org/faostat/. (Accessed: 1 May 2021)

Globenewswire (2019) Saudi Arabia Natural \& Organic Food Industry Report 2019. doi: 10.1017/ CBO9781107415324.004.

Grand View Research, I. (2017) Facades Market Size Worth \$337.8 Billion By 2025. Available at: https://www.grandviewresearch.com/press-release/global-facades-market. Incomplete. (Accessed: 17 September 2020)

Hanemann, M., Loomis, J. and Kanninen, B. (1991) 'Statistical Efficiency of Double-Bounded Dichotomous Choice Contingent Valuation', American Journal of Agricultural Economics, 73(4), pp. 1255-1263. doi: 10.2307/1242453

Hanemann, W. M. (1984) 'Welfare Evaluations in Contingent Valuation Experiments with Discrete Responses', American Journal of Agricultural Economics, 60(3), pp. 332-341. doi: 
Hole, A. R. (2007) 'A comparison of approaches to estimating confidence intervals for willingness to pay measures', Health Economics, 16(8), pp. 827-840. doi: 10.1002/hec.1197.

Huang, C. H. and Lee, C. H. (2014) 'Consumer willingness to pay for organic fresh milk in Taiwan', China Agricultural Economic Review, 6(2), pp. 198-211. doi: 10.1108/CAER-04-2012-0033.

Krystallis, A. and Chryssohoidis, G. (2005) 'Consumers' willingness to pay for organic food: Factors that affect it and variation per organic product type', British Food Journal, 107(5), pp. 320-343. doi: 10.1108/00070700510596901.

Ministry of Environment, W. and A. (2019) Domestic Agricultural Production Sector Achieves High Sufficiency Ratio. Available at: https://www.mewa.gov.sa/ar/MediaCenter/News/Pages/ News1004.aspx. (Accessed: 17 September 2020)

Muhammad, S., Fathelrahman, E. and Ullah, R. U. T. (2015) 'Factors Affecting Consumers' Willingness to Pay for Certified Organic Food Products in United Arab Emirates.', Journal of Food Distribution Research, 46(1), pp. 37-45. Available at: http://search.ebscohost.com/ login.aspx direct $=$ true $\& d b=b$ th $\& A N=109155789 \&$ site $=$ ehost-live \&scope $=$ site.

Nagy-Pércsi, K. and Fogarassy, C. (2019) 'Important influencing and decision factors in organic food purchasing in Hungary’, Sustainability (Switzerland), 11(21), pp. 1-21. doi: 10.3390/ su11216075.

Padilla Bravo, C. et al. (2013) 'Assessing determinants of organic food consumption using data from the German National Nutrition Survey II', Food Quality and Preference, 28(1), pp. 60-70. doi: 10.1016/j.foodqual.2012.08.010.

Scozzafava, G. et al. (2020) 'Organic milk preference: is it a matter of information?', Appetite, 144(February 2019), p. 104477. doi: 10.1016/j.appet.2019.104477.

Vaughan, W. and Darling, A. (2000) The Optimal Sample Size for Contingent Valuation Surveys : Applications to Project Analysis. Washington, D.C. Available at: https://publications.iadb. org/publications/english/document/The-Optimal-Sample-Size-for-Contingent-ValuationSurveys-Applications-to-Project-Analysis.pdf.

Voon, J. P., Ngui, K. S. and Agrawal, A. (2011) 'Determinants of willingness to purchase organic food: An exploratory study using structural equation modeling', International Food and Agribusiness Management Review, 14(2), pp. 103-120.

Ward, P. R. et al. (2012) 'The Social Determinants of Food Purchasing Practices: Who Chooses Price-before-Health, Taste-before-Price or Organic Foods in Australia?', Food and Nutrition Sciences, 03(04), pp. 461-470. doi: 10.4236/fns.2012.34066.

Zohra Ghali-Zinoubi (2020) 'On linking socioeconomic status to consumer willingness to buy and pay for organic food', Journal of Food Science and Technology, 58(3), pp. 1042-1050. 